\title{
Biosynthesis of $\beta$-Glucan Microfibrils by Cell-free Extracts from Saccharomyces cerevisiae
}

\author{
By G. LARRIBA, $\uparrow$ M. MORALES AND J. RUIZ-HERRERA* \\ Departamento de Genética y Biología Molecular, Centro de Investigación y Estudios \\ Avanzados del Instituto Politécnico Nacional, México 14, D.F. México, and \\ Instituto de Investigación en Biología Experimental, Facultad de Química, University of \\ Guanajuato, México
}

(Received 27 June 1980; revised 30 October 1980)

Glucan synthase activity in cell-free extracts of Saccharomyces cerevisiae was partially stabilized when cells were broken in the presence of sucrose. Under these conditions a significant amount of enzyme activity remained in the supernatant after high-speed centrifugation. When this supernatant fraction was incubated with UDPglucose, microfibrils were synthesized. Microfibrils were insoluble in water, ethanol and acid, and soluble in alkali. Under the electron microscope they appeared more or less uniform with an average length of about $0.5 \mu \mathrm{m}$. Alkali-insoluble residue appeared in the form of densely-packed longer microfibrils. After acidification of alkali-solubilized glucan, shorter microfibrils were reprecipitated. Microfibrils were digested by both endo- and exo-1,3- $\beta$-glucanase. In the latter case, glucose was the only product indicating that the microfibrils consist of $1,3-\beta$-glucan with no detectable branches.

\section{INTRODUCTION}

Studies carried out in our laboratory demonstrated the biosynthesis of significant amounts of $\beta$-glucans by membrane-rich fractions from Saccharomyces cerevisiae (López-Romero \& Ruiz-Herrera, 1977, 1978). We found that glucan synthase was specific for UDPglucose, did not require a divalent metal, was inhibited by UDP and was extremely unstable. These results were confirmed by Shematek et al. (1980).

In the present communication we describe experiments which led to the preservation of $\beta$-glucan synthase activity during cell breakage, to its partial stabilization and to the synthesis of $\beta$-glucan microfibrils in vitro. A preliminary account of this work has appeared elsewhere (Larriba et al., 1980).

\section{METHODS}

Yeast strain and culture conditions. Saccharomyces cerevisiae strain EL was grown in a yeast extract, peptone and glucose (YPG) medium as previously described (López-Romero \& Ruiz-Herrera, 1977) and harvested in early-exponential phase.

Preparation of cell-free extracts. Cells were washed and resuspended in either Tris/magnesium/EDTA (TME) buffer (López-Romero \& Ruíz-Herrera, 1977) or TME buffer containing 1 M-sucrose; they were mixed with glass beads and broken for $60 \mathrm{~s}$ in a MSK Braun homogenizer (Braun, Melsungen, F.R.G.). Cell walls were removed by centrifugation at $2700 \mathrm{~g}$ for $5 \mathrm{~min}$. The supernatant was centrifuged at $54000 \mathrm{~g}$ for $1 \mathrm{~h}$ to separate a membrane-rich fraction (MMF) and a supernatant.

Glucan synthase assay. Glucan synthase (UDPglucose: 1,3- $\beta$-D-glucan 3 - $\beta$-D-glucosyltransferase; EC 2.4 .1 .34 ) incubation mixtures (final volume $125 \mu \mathrm{l})$ contained $0.4 \mathrm{mM}$-UDP[U-14 $\mathrm{C}$ ]glucose $\left(0.5 \mathrm{Ci} \mathrm{mol}^{-1}\right)$, $7 \mathrm{~mm}$-cellobiose, $5 \mathrm{mM}-\mathrm{MgCl}_{2}, 1 \mathrm{~mm}$-EDTA, $20 \mu \mathrm{g} \alpha$-amylase $\mathrm{ml}^{-1}, 0.05 \mathrm{M}$-Tris/ $\mathrm{HCl}$ buffer $\mathrm{pH} 7.0$ and enzyme

$\dagger$ On leave from the Facultad de Ciencias, University of Salamanca, Spain. 
fraction $\left(0.1\right.$ to $0.5 \mathrm{mg}$ protein), and were incubated at $22^{\circ} \mathrm{C}$. Unless otherwise stated, the reaction was stopped after $30 \mathrm{~min}$ by adding 2 vol. ethanol and the whole mixture was filtered through glass-fibre filters (Schleicher \& Schüll, no. 8; Dassel, F.R.G.). The filters and retained material were washed twice with $20 \mathrm{ml}$ each of $66 \%(\mathrm{v} / \mathrm{v})$ ethanol, $5 \%(\mathrm{w} / \mathrm{v})$ trichloroacetic acid and $50 \%$ ethanol, and then dried and counted in a Packard Tricarb model C2425 liquid scintillation spectrometer. $\beta$-Glucan synthase activity was expressed as nmol glucose incorporated into $\beta$-glucan in $1 \mathrm{~min}$; specific activity was calculated per $\mathrm{mg}$ protein. When analysis of residual substrate and by-products was intended, incubation mixtures were treated with 2 vol. ethanol and insoluble glucan was recovered by centrifugation. Supernatants were subjected to paper chromatography and radioactivity was measured (see below). The pellet was washed with $66 \%$ ethanol and its radioactivity was counted.

Preparation of microfibrils with high specific radioactivity. Supernatant fraction (19.5 $\mathrm{mg}$ protein) was incubated with $0.45 \mathrm{~mm}$-UDP[U- $\left.{ }^{14} \mathrm{C}\right]$ glucose $\left(0.34 \mathrm{Ci} \mathrm{mol}^{-1}\right), 2.5 \mathrm{~mm}$-cellobiose and $180 \mu \mathrm{g} \alpha$-amylase $\mathrm{ml}^{-1}$ in a final volume of $32.5 \mathrm{ml}$ TME buffer. At intervals, samples were withdrawn, mixed with ethanol and filtered as described above. After $2 \mathrm{~h}$ incubation, the mixture was cooled and centrifuged at $56000 \mathrm{~g}$ for $1 \mathrm{~h}$. The supernatant was discarded and the sediment was washed five times with water by centrifugation at $4000 \mathrm{~g}$.

Chromatography. Descending paper chromatography was carried out on Whatman no. 1 sheets or $3 \mathrm{MM}$ strips using the following solvents: (a) $95 \%$ ethanol/1 M-acetic acid $(7: 3$, by vol.); (b) ethyl acetate/pyridine/water (10:4:3, by vol.); (c) methyl ethyl ketone/boric acid-saturated water/acetic acid $(9: 1: 1$, by vol.). Gel filtration was carried out in a Biogel P2 column $(80 \times 2.5 \mathrm{~cm})$. Samples were applied in $0.1 \mathrm{M}$-acetic acid and eluted with the same solution at a flow rate of $0.2 \mathrm{ml} \mathrm{min}^{-1} ; 1 \mathrm{ml}$ samples were collected.

Chemical procedures. Protein was measured by the Lowry method. Sugars in solution were measured with the anthrone reagent (Ashwell, 1957). Reducing sugars were located on paper chromatograms with alkaline $\mathrm{AgNO}_{3}$ (Trevelyan et al., 1950). Radioactive spots on chromatograms were detected with a Packard model 7230 two-dimensional radiochromatogram scanner or as described previously (López-Romero \& Ruiz-Herrera, 1977). $\beta$-Elimination was performed in $0.1 \mathrm{M}-\mathrm{NaOH}$ containing $0.1 \mathrm{M}-\mathrm{NaBH}_{4}$ or $\mathrm{NaB}^{3} \mathrm{H}_{4}\left(5 \mathrm{mCi} ; 360 \mathrm{Ci} \mathrm{mmol}{ }^{-1}\right)$ at $37^{\circ} \mathrm{C}$ for $48 \mathrm{~h}$. Samples were then diluted twice with water, acidified with glacial acetic acid and centrifuged. Pellets were washed with water. Acetylation of sugars was carried out overnight with $0.2 \mathrm{ml}$ acetic anhydride in $0.3 \mathrm{ml}$ pyridine. Solvents were eliminated under reduced pressure in a flash evaporator after addition of an excess of toluene. Compounds were deacetylated with $0.2 \mathrm{M}-\mathrm{NaOH}$ in methanol $(1: 1, \mathrm{v} / \mathrm{v})$ for $45 \mathrm{~min}$ at $25^{\circ} \mathrm{C}$. $\left[{ }^{14} \mathrm{C}\right]$ Glucitol, $\left[{ }^{14} \mathrm{C}\right]$ mannitol and $\mathrm{N}$-acetyl $\left[{ }^{14} \mathrm{C}\right]$ glucosaminitol were prepared by treatment of the corresponding ${ }^{14} \mathrm{C}$-labelled aldoses with $0.1 \mathrm{M}-\mathrm{NaBH}_{4}$. After acidification, samples were passed through a Dowex $50 \mathrm{H}^{+}$column and eluted with water. Boric acid was volatilized as methyl borate.

Electron microscopy. For negative staining, droplets of sample were placed on carbon-coated Formvar films on 200-mesh copper grids. The grids were floated sample side down on $25 \%(\mathrm{v} / \mathrm{v}$ ) glutaraldehyde in $0 \cdot 1 \mathrm{M}$-cacodylate buffer $\mathrm{pH} 7 \cdot 1$, washed with water, stained with $2 \cdot 0 \%(\mathrm{w} / \mathrm{v})$ aqueous uranyl acetate and excess was withdrawn with filter paper. For shadow-casting, samples were evaporated on Formvar-coated grids. Specimens were shadow-cast with carbon-platinum in a Balzers 300 instrument at a $25^{\circ}$ angle and then with carbon at a $90^{\circ}$ angle to stabilize the material. Specimens were examined and photographed with a Zeiss EM-10 electron microscope.

Chemicals. UDP[U- ${ }^{14} \mathrm{C}$ ]glucose $\left(240 \mathrm{Ci} \mathrm{mol}^{-1}, 8.88 \mathrm{TBq} \mathrm{mol}^{-1}\right)$ and $\mathrm{NaB}^{3} \mathrm{H}_{4}\left(360 \mathrm{Ci} \mathrm{mmol}^{-1}, 13.32 \mathrm{TBq}\right.$ $\mathrm{mmol}^{-1}$ ) were purchased from New England Nuclear. UDPglucose and bacterial $\alpha$-amylase were from Sigma. Biogel P2 was from Bio-Rad. Purified endo-1,3- $\beta$-glucanase from Rhizopus QM1032 and exo-1,3- $\beta$-glucanase from Sporotrichum dimorphosporum (Basidiomycete QM806) were a kind gift from E. T. Reese (U.S. Army Laboratories, Natick, Mass., U.S.A.). All other chemicals were of reagent grade.

\section{RESULTS}

\section{Effect of protease inhibitors and osmotic stabilizers on glucan synthase activity}

Glucan synthase is unstable (López-Romero \& Ruiz-Herrera, 1978). Addition of protease inhibitors (phenylmethane sulphonyl fluoride, pepstatin, leupeptin) either alone or in mixtures to the breakage medium did not enhance glucan synthase stability, suggesting that the enzyme was not inactivated through a proteolytic mechanism.

By adding $0 \cdot 2-2.0 \mathrm{M}$-sucrose to the breakage medium as an osmotic protectant, we obtained higher enzyme yields. Of the different concentrations tested we obtained best results with 1 M-sucrose (10-20 times more activity than controls). Addition of $10 \%$ glycerol to breakage medium gave intermediate protection, whereas addition of sucrose after cell breakage was completely ineffective (Fig. 1). Addition of $10 \%$ glycerol to control membrane-rich fraction (MMF) caused $50 \%$ inhibition.

Glucan formation proceeded linearly only for 30-60 min and then it declined and stopped 


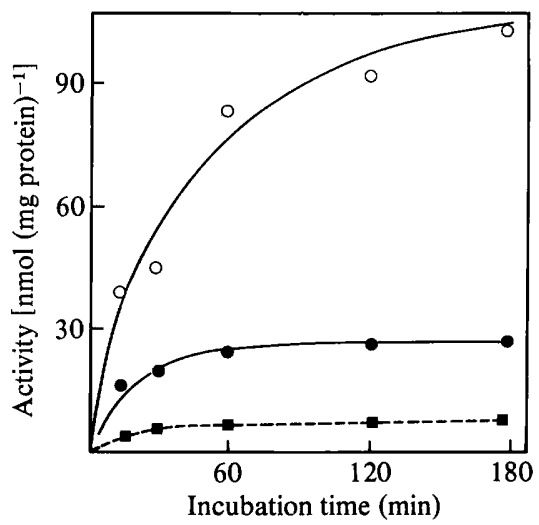

Fig. 1. Effect of sucrose and glycerol on $\beta$-glucan synthase activity. Cells were broken in TME buffer either alone or containing $1 \mathrm{M}$-sucrose or $10 \%(\mathrm{v} / \mathrm{v})$ glycerol. After removal of cell walls, the membrane-rich fraction (MMF) was sedimented and resuspended in the corresponding solutions. At intervals, samples were withdrawn and assayed for glucan synthase activity: MMF from cells broken with sucrose (O), MMF from cells broken with glycerol (O) and MMF from cells broken with TME buffer alone and incubated in buffer alone or with $1 \mathrm{M}$-sucrose ( $\square$ ).

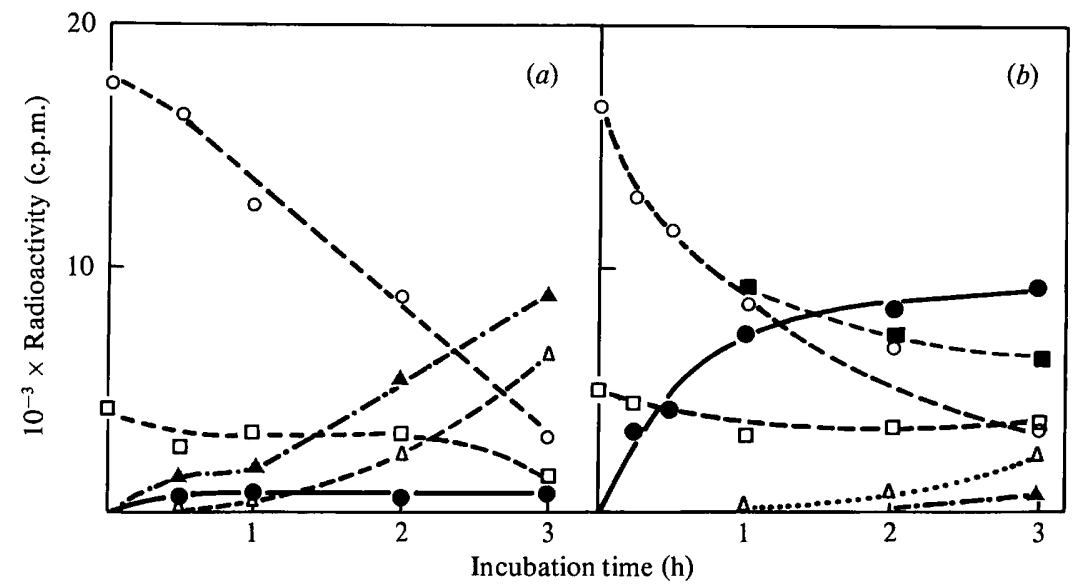

Fig. 2. Substrate disappearance and formation of products by MMF. MMF prepared in buffer ( $a$ ) or in buffer plus $1 \mathrm{M}$-sucrose $(b)$ was incubated with UDP[U- $\left.{ }^{14} \mathrm{C}\right]$ glucose. At intervals, samples were withdrawn and analysed for residual UDP $\left[\mathrm{U}^{14} \mathrm{C}\right]$ glucose $(\mathrm{O})$, glucose phosphate $(\square)$, glucose $(\boldsymbol{\Delta})$, glucan $(\bigcirc)$ and the sum of two unknown anionic compounds $(\triangle)$. The glucose phosphate present at the start of reaction was contaminating material of the substrate. Also shown is the theoretical disappearance of UDPglucose if no by-products were formed ( $\square$ ).

completely, especially when cells were broken in the absence of sucrose (Fig. 1). This decline was possibly due to enzyme instability and to substrate degradation by contaminating pyrophosphatases and phosphatases. Analysis of reaction mixtures by paper chromatography revealed that, in the absence of sucrose, glucose, glucose phosphate and two unknown compounds more polar than the latter were accumulated (Fig. $2 a$ ), whereas in the presence of sucrose, substrate was stoichiometrically incorporated into glucan for at least $1 \mathrm{~h}$, and minimal amounts of by-products were formed (Fig. $2 b$ ). That glucose and the unknown compounds were not products of glucan degradation was suggested by the fact that enzyme fractions did not degrade laminarin or radioactive $\beta$-glucan synthesized in vitro. It should be noted that in the absence of sucrose, $\beta$-glucan biosynthesis stopped when the substrate concentration was still high (Fig. $2 a$ ). 
Table 1. Distribution of glucan synthase in cell-free extracts obtained with and without sucrose

$\begin{array}{ccllcc}\begin{array}{c}\text { Sucrose in } \\ \text { breakage medium }\end{array} & \begin{array}{c}\text { Time of } \\ \text { breakage } \\ \text { (s) }\end{array} & \text { Fraction } & \overbrace{\begin{array}{c}\text { Specific } \\ \text { activity* }\end{array}}^{\text {Glucan synthase }} & \begin{array}{c}\text { Total } \\ \text { activity } \dagger\end{array} & \begin{array}{c}\text { Distribution } \\ \text { (\%) }\end{array} \\ \text { Absent } & 60 & \begin{array}{l}\text { MMF } \\ \text { Supernatant }\end{array} & \begin{array}{l}0.093 \\ 0.0005\end{array} & 1.432 & 96 \\ \text { Present } & 60 & \text { MMF } & 0.941 & 11.668 & 31 \\ & & \text { Supernatant } & 0.546 & 26.208 & 69 \\ \text { Present } & 120 & \begin{array}{l}\text { MMF } \\ \text { Supernatant }\end{array} & 1.060 & 19.50 & 80 \\ & & & 0.128 & 4.90 & 20\end{array}$

\footnotetext{
* Expressed as nmol glucose incorporated (mg protein $)^{-1} \mathrm{~min}^{-1}$.

$\dagger$ Expressed as nmol glucose incorporated $\mathrm{min}^{-1}$ in the whole fraction. Activity present in cell walls was not taken into consideration.
}

\title{
Table 2. Stability of $\beta$-glucan synthase at $4^{\circ} \mathrm{C}$
}

\begin{abstract}
Supernatant fraction was obtained from cells broken in the presence of $1 \mathrm{M}$-sucrose. MMF was obtained from cells broken without sucrose. Fractions were incubated at $4{ }^{\circ} \mathrm{C}$; at the indicated times, samples were removed and glucan synthase activity was measured.
\end{abstract}

\begin{tabular}{|c|c|c|}
\hline \multirow{2}{*}{$\begin{array}{l}\text { Time of } \\
\text { incubation } \\
\text { (h) }\end{array}$} & \multicolumn{2}{|c|}{$\begin{array}{c}\text { Specific activity } \\
{\left[\mathrm{nmol} \min ^{-1}(\mathrm{mg} \text { protein })^{-1}\right]}\end{array}$} \\
\hline & $\begin{array}{l}\text { Supernatant } \\
\text { (1 M-sucrose) }\end{array}$ & $\begin{array}{c}\text { MMF } \\
\text { (no sucrose) }\end{array}$ \\
\hline 0 & 0.529 & 0.089 \\
\hline 19 & 0.394 & 0 \\
\hline 33 & 0.351 & - \\
\hline 129 & 0.218 & - \\
\hline
\end{tabular}

\section{Distribution of glucan synthase in cell-free extracts}

The supernatant fraction from cells broken in buffer had almost no glucan synthase activity (Table 1), in agreement with previous data (López-Romero \& Ruiz-Herrera, 1977). On the other hand, breakage in the presence of sucrose preserved a substantial amount of glucan synthase activity in the supernatant (Table 1). The proportion of the total enzyme activity that was present in this supernatant fraction varied between 20 and $80 \%$ in different experiments. The variability is probably due to a greater lability of the enzyme in this fraction compared with that found in MMF, since increasing the time of breakage did not alter the activity of enzyme present in MMF but was noticeably deleterious to enzyme present in the supernatant (Table 1).

\section{Stability of glucan synthase}

Glucan synthase activity present in extracts prepared without sucrose was very unstable at $4{ }^{\circ} \mathrm{C}$, but that from extracts obtained with sucrose was fairly stable at $4{ }^{\circ} \mathrm{C}$ (Table 2 ). However, all extracts were rapidly inactivated at room temperature. Addition of $\mathrm{NaF}$ to sucrose in the breakage medium helped to stabilize glucan synthase at $28^{\circ} \mathrm{C}$ (Fig. 3). Addition of $\mathrm{NaF}$ to cell extracts stimulated glucan synthase activity (Table 3 ) but had no effect on stability (Fig. 4); however, when $\mathrm{NaF}$ was added with nucleoside triphosphates, $\beta$-glucan synthase stability was enhanced. GTP was more effective than ATP. Both ATP and 


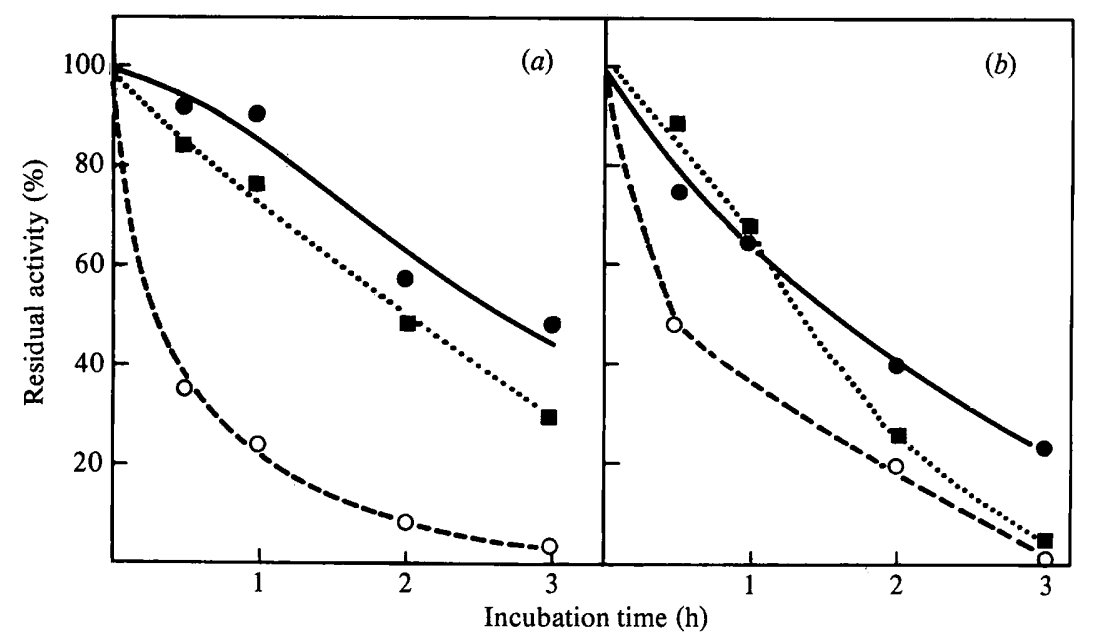

Fig. 3. Effect of $\mathrm{NaF}$ on $\beta$-glucan synthase stability. MMF (a) or supernatant $(b)$ obtained in the presence of $1 \mathrm{M}$-sucrose together with $0.25 \mathrm{M}-\mathrm{NaF}(\mathrm{O})$, or with $0.5 \mathrm{M}-\mathrm{NaF}(\square)$ or without $\mathrm{NaF}(\mathrm{O})$ was incubated at $28^{\circ} \mathrm{C}$. At intervals, samples were withdrawn and assayed for glucan synthase activity; for each incubation mixture activities are expressed as a percentage of that at the start of incubation.

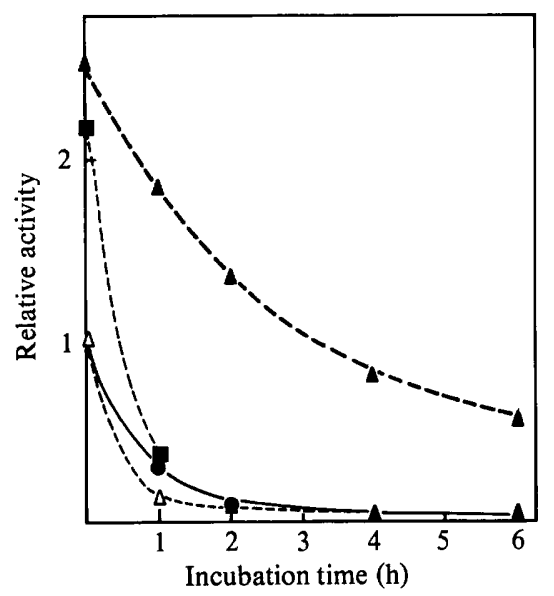

Fig. 4. Effect of NaF and GTP on $\beta$-glucan synthase stability. Cells were broken in TME buffer containing sucrose, and MMF was incubated at $28^{\circ} \mathrm{C}$ without additions (O), with $0.5 \mathrm{M}-\mathrm{NaF}(\mathbf{\square})$, with $0.5 \mathrm{mM}$-GTP $(\triangle)$ or with $0.5 \mathrm{M}-\mathrm{NaF}$ plus $0.5 \mathrm{~mm}$-GTP $(\Delta)$. At intervals, samples were withdrawn and assayed for glucan synthase activity; activities are expressed relative to that of MMF without addition at the start of incubation.

\section{Table 3. Effect of nucleoside triphosphates and NaF on $\beta$-glucan synthase}

\begin{tabular}{|c|c|c|c|}
\hline \multirow[b]{2}{*}{$\begin{array}{l}\text { Breakage } \\
\text { medium }\end{array}$} & \multirow{2}{*}{$\begin{array}{c}\text { Nucleoside } \\
\text { triphosphate added }\end{array}$} & \multicolumn{2}{|c|}{$\begin{array}{c}\text { Specific activity } \\
{\left[\mathrm{nmol} \min ^{-1}(\mathrm{mg} \text { protein })^{-1}\right]}\end{array}$} \\
\hline & & Without NaF & With $0.5 \mathrm{M}-\mathrm{NaF}$ \\
\hline Buffer & $\operatorname{GTP}(\overline{0.1} \mathrm{~mm})$ & $\begin{array}{l}0.006 \\
0.006\end{array}$ & $\begin{array}{l}0.008 \\
0.046\end{array}$ \\
\hline $\begin{array}{l}\text { Buffer containing } \\
1 \mathrm{M} \text {-sucrose }\end{array}$ & $\begin{array}{l}-\overline{\operatorname{ATP}}(0.01 \mathrm{~mm}) \\
\operatorname{ATP}(0.1 \mathrm{~mm}) \\
\operatorname{GTP}(0.01 \mathrm{mM}) \\
\operatorname{GTP}(0.1 \mathrm{~mm})\end{array}$ & $\begin{array}{l}0.131 \\
0.122 \\
0.121 \\
0.098 \\
0.094\end{array}$ & $\begin{array}{l}0.155 \\
0.162 \\
0.237 \\
0.166 \\
0.326\end{array}$ \\
\hline
\end{tabular}


GTP stimulated glucan synthase only when cells were broken with sucrose, and especially when $\mathrm{NaF}$ was present (Table 3).

Dialysis of extracts at $4{ }^{\circ} \mathrm{C}$ provoked inactivation of glucan synthase. This inactivation was not due to loss of sucrose since identical results were obtained when samples were dialysed against buffer containing $1 \mathrm{M}$-sucrose.

\section{Nature of the product synthesized in the presence of sucrose}

The product synthesized by both MMF and high-speed supernatant obtained in the presence of sucrose was completely resistant to $\alpha$-amylase. It was completely solubilized by exo-1,3- $\beta$-glucanase. Treatment for $2 \mathrm{~h}$ with endo-1,3- $\beta$-glucanase solubilized about $70 \%$ of the initial radioactivity. Incubation of scaled-up reaction mixtures with the supernatant fraction gave rise to the formation of an insoluble product visible to the naked eye. In two different experiments $24 \mathrm{mM}-\mathrm{UDP}\left[\mathrm{U}^{-14} \mathrm{C}\right] \mathrm{glucose}\left(1.3 \mathrm{mCi} \mathrm{mol}{ }^{-1}\right)$ was incubated with the supernatant fraction in a total volume of $3.2 \mathrm{ml}$ with TME buffer, amylase and cellobiose. After $7 \mathrm{~h}$, insoluble material was recovered by centrifugation at $4000 \mathrm{~g}$ and washed with water until the supernatants were free of radioactive material. Insoluble glucan amounted to 0.22 and $0.25 \mathrm{mg}$, respectively, as determined by radioactivity. Samples of the product were examined by electron microscopy using both shadow-cast and negative-staining procedures. $\beta$-Glucan appeared as entangled masses of microfibrils almost free of contaminating material (Fig. 5). The size of microfibrils in these masses was difficult to ascertain, but in selected regions where microfibrils appeared more separate an average length of $0.48 \pm$ (s.D.) $0.11 \mu \mathrm{m}$ was determined. In shadow-cast preparations, microfibrils looked somewhat flattened. This was more noticeable in negatively stained samples (Fig. 6) where twisted microfibrils were occasionally observed. The width of the microfibrils was fairly uniform giving values of about $15 \mathrm{~nm}$ and $10 \mathrm{~nm}$, respectively, for the cross-section.

When samples were incubated to prepare microfibrils with high specific radioactivity (see Methods), a total of $580 \mu \mathrm{g}$ glucan was obtained (calculated by radioactivity) which corresponded to $22 \%$ incorporation of glucose. In the electron microscope, the morphology of the glucan microfibrils was identical to that shown in Figs 5 and 6. A sample of microfibrils $\left(290 \mu \mathrm{g}, 1.2 \times 10^{6} \mathrm{~d}\right.$.p.m.) was incubated with $4.5 \mathrm{mg}$ exo-1,3- $\beta$-glucanase in $0.05 \mathrm{M}$-sodium acetate buffer $\mathrm{pH} 4.8$ at $45^{\circ} \mathrm{C}$ for $72 \mathrm{~h}$. A crystal of thymol was added as a preservative. Examination of samples of the hydrolysate by electron microscopy revealed complete disappearance of microfibrils and centrifugation at high speed left all radioactivity in the supernatant. When analysed by gel filtration, all the radioactivity eluted as a single symmetrical peak with the same elution volume as glucose. This was identified by paper chromatography in solvent $(b)$. Microfibrils were also completely solubilized by endo$1,3-\beta$-glucanase but were unaffected by amylase. They were partially soluble in dilute alkali and almost completely soluble in $0.3 \mathrm{M}-\mathrm{NaOH}$ (Table 4). Electron microscopy of the alkali-insoluble residue revealed microfibrils similar though rather longer than those soluble in alkali and packed in parallel arrays (Fig. 7). Microfibrils were completely insoluble in water, acid and ethanol (Table 4). After solubilization with alkali they could be reprecipitated by acidification (Table 4). The reprecipitated glucan looked different to the original microfibrils under the electron microscope (Fig. 8). It appeared more crystalline-like in the form of short 'chips' about $0 \cdot 1-0 \cdot 15 \mu \mathrm{m}$ in length and wider than the original microfibrils. These short 'chips' appeared to be formed by the association of thinner microfibrils.

$\beta$-Elimination of ${ }^{14} \mathrm{C}$-labelled microfibrils did not solubilize any radioactive material. In further experiments $\beta$-elimination of radioactive microfibrils was carried out in the presence of $\mathrm{NaB}^{3} \mathrm{H}_{4}$. Microfibrils thus treated were then hydrolysed with $4 \mathrm{M}-\mathrm{HCl}$ at $100^{\circ} \mathrm{C}$ and the hydrolysate was neutralized with $\mathrm{NaOH}$. Samples were evaporated, fully acetylated and partitioned in chloroform/methanol/water $(10: 5: 1$, by vol.); and the lower phase was washed with methanol/water $\left(1: 1\right.$, by vol.). About $90 \%$ of ${ }^{14} \mathrm{C}$ radioactivity became soluble in the organic phase. Samples were deacetylated and the products were analysed by paper 

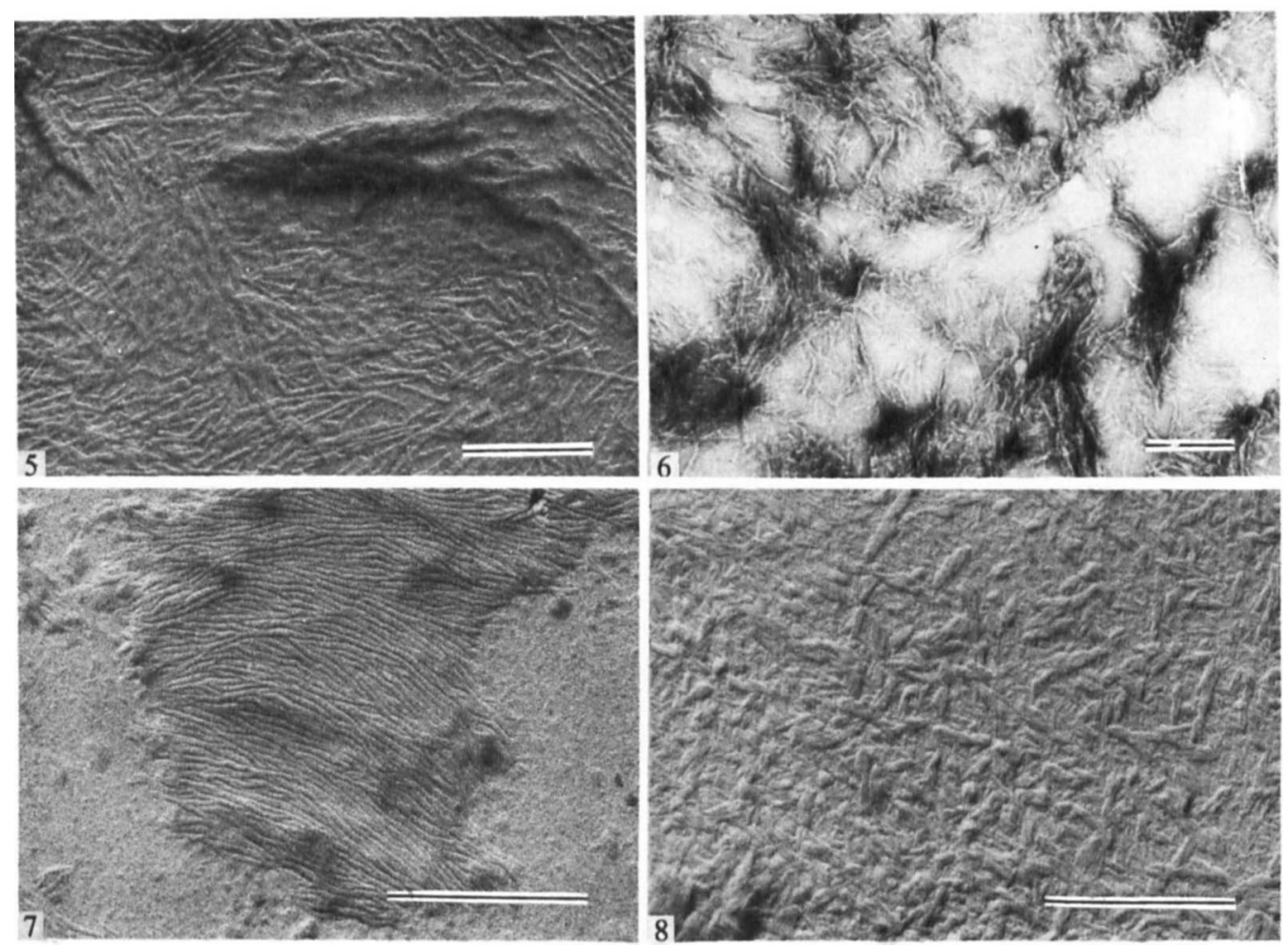

All the bar markers represent $500 \mathrm{~nm}$.

Fig. 5. Shadow-cast sample of $\beta$-glucan microfibrils synthesized in vitro.

Fig. 6. Negatively stained sample of $\beta$-glucan microfibrils.

Fig. 7. Shadow-cast residue left after solubilization of $\beta$-glucan with $0.5 \mathrm{M}-\mathrm{NaOH}$.

Fig. 8. Shadow-cast sample of reprecipitated microfibrils obtained after neutralization of alkalisolubilized $\beta$-glucan.

\section{Table 4. Solubility of $\beta$-glucan microfibrils synthesized in vitro}

Samples of radioactive microfibrils ( 6000 d.p.m.) were mixed with $500 \mu$ l of each potential solvent and allowed to stand for $20 \mathrm{~min}$ at $25^{\circ} \mathrm{C}$. Insoluble material was recovered on glass-fibre filters, washed twice with $20 \mathrm{ml}$ of the corresponding solvent and once with $20 \mathrm{ml}$ of $50 \%(\mathrm{v} / \mathrm{v})$ ethanol. Filters were dried and counted.

\section{Solvent $\quad \begin{aligned} & \text { Percentage } \\ & \text { solubilized }\end{aligned}$}

$\begin{array}{lr}\text { Water } & 0 \\ \text { Ethanol }(66 \%, \mathrm{v} / \mathrm{v}) & 0 \\ \text { Acetic acid }(0.5 \mathrm{M}) & 3 \\ \mathrm{NaOH}(0.2 \mathrm{M}) & 68 \\ \mathrm{NaOH}(0.3 \mathrm{M}) & 85 \\ \mathrm{NaOH}(0.3 \mathrm{M}), \text { then acetic acid }(0.5 \mathrm{M}) & 11\end{array}$

chromatography in solvent $(c)$. All ${ }^{14} \mathrm{C}$ co-chromatographed with glucose: no ${ }^{3} \mathrm{H}$ or ${ }^{14} \mathrm{C}$ co-chromatographed with glucitol, mannitol or $N$-acetylglucosaminitol. Most of the ${ }^{3} \mathrm{H}$ migrated with the solvent front and was lost during dipping. Treatment of ${ }^{14} \mathrm{C}$-labelled microfibrils with $\mathrm{NaB}^{3} \mathrm{H}_{4}$ alone gave similar results. 


\section{DIS CUSSION}

The enhancement of $\beta$-glucan synthase activity and stability by sucrose is noticeable. Apparently, sucrose decreases the release of destructive agents during cell breakage. Among these are pyrophosphatases and phosphatases that degrade substrate. Sucrose may help to preserve an activating low molecular weight factor which can be eliminated by dialysis. The stabilizing effect of $\mathrm{NaF}$ was surprising. It was added firstly as a potential inhibitor of substrate-degrading contaminating enzymes, but later we realized that it also enhanced the stability of glucan synthase. The effects of sucrose, $\mathrm{NaF}$ and nucleoside triphosphates are consistent with the following tentative scheme. Active glucan synthase requires a low molecular weight factor which is present in a phosphorylated form. This factor is phosphorylated by a reaction which requires ATP or GTP, and it is dephosphorylated by phosphatases present in an osmotically fragile compartment. Breakage in the presence of sucrose prevents phosphatase release, and fluoride inhibits phosphatase activity. Therefore, addition of both compounds plus a nucleoside triphosphate helps to stabilize glucan synthase. These ideas complement those expressed by Shematek \& Cabib (1980).

The use of sucrose in the breakage medium allowed us to detect a substantial amount of $\beta$-glucan synthase in the supernatant fraction. Apparently due to its lability, this enzyme fraction had been overlooked in previous studies (López-Romero \& Ruíz-Herrera, 1977). The finding of this enzyme fraction allowed us to obtain synthesis of $\beta$-glucan microfibrils by cell-free extracts from yeast in vitro. These microfibrils were easily visualized since they were sedimented with almost no proteinaceous contaminating material. The glucan microfibrils were much shorter than those of chitin synthesized by chitosomes from $S$. cerevisiae (Bartnicki-García et al., 1978), and roughly similar to microfibrils synthesized in vitro by membrane-rich fraction from Phytophthora cinnamomi (Wang \& Bartnicki-García, 1976) and Paracoccidioides brasiliensis (San Blas, 1979), except those from S. cerevisiae looked more regular. The microfibrils of $S$. cerevisiae were mostly soluble in alkali, leaving an insoluble fraction consisting of a parallel array of longer microfibrils. It is possible that insolubility of a certain fraction of glucan is due to different chain packing; even the possibility that it represents different length chains cannot be excluded. Recrystallized microfibrils were shorter, showed a 'quasi' crystalline arrangement and looked similar to 'hydroglucan' microfibrils observed in cell walls of $S$. cerevisiae subjected to boiling with $\mathrm{HCl}$ (Fleet \& Manners, 1976). No such a difference between 'native' and reprecipitated microfibrils was observed in P. cinnamomi (Wang \& Bartnicki-García, 1976).

On the basis of the proposed structure of linear 1,3- $\beta$-glucan (Bluhm \& Sarko, 1977), we have calculated that native microfibrils are made of about 80 chains containing around 700 glucose units each (if no gaps exist in the linear chains). This last value is in the range of those reported by Fleet \& Manners (1976) for the alkali-soluble glucan extracted from the cell wall of $S$. cerevisiae. Since no gentiobiose or other disaccharide was produced by exhaustive digestion of microfibrils with exo-1,3- $\beta$-glucanase, we conclude that they are made exclusively of $1,3-\beta$-linked glucose chains with no branches. Similar results were obtained with regenerating protoplasts from $S$. cerevisiae (Kreger \& Kopecka, 1976) where a net of microfibrils of unbranched $1,3-\beta$-glucan is made, with microfibrils synthesized by cell extracts of $P$. cinnamomi (Wang \& Bartnicki-García, 1976) and with a short-chain glucan from $S$. cerevisiae (Shematek et al., 1980), all of which are 1,3- $\beta$-glucans lacking 1,6- $\beta$-linkages.

All glucans present in the cell wall of $S$. cerevisiae contain $1,6-\beta$-linkages, to a variable degree, either as side-chains or serving as interchain linkages (Manners et al., 1973; Fleet \& Manners, 1976). Moreover, we have previously obtained synthesis of $\beta$-glucans containing $1,6-\beta$-linkages by both membrane-rich and cell wall fractions (López-Romero \& RuízHerrera, 1977). Noticeably, glucan synthesized by the wall fraction contained more $1,6-\beta$-linked residues than that synthesized by the membrane-rich fraction. It seems unlikely that the repeated observation that wall-free cells and cell fractions synthesize only $1,3-\beta$-glucan is a mere coincidence. Therefore, our previous suggestion (López-Romero \& 
Ruiz-Herrera, 1977) that $1,6-\beta$-glucosyl transferase (branching enzyme?) is mostly bound to the cell wall seems pertinent. We did not detect the formation of any short oligosaccharides susceptible to $\beta$-elimination like those reported by Balint et al. $(1976)$. Absence of $\left[{ }^{3} \mathrm{H}\right]$ glucitol among the products of $\beta$-elimination in the presence of $\mathrm{NaB}^{3} \mathrm{H}_{4}$ followed by hydrolysis of microfibrils argues against the presence of any $O$-glycosidic bond between the glucan chain and a protein. However, these experiments revealed that the reducing end of the 1,3- $\beta$-glucan chains is bound to an acceptor different from glucose, mannose or $N$-acetylglucosamine. The nature of this acceptor is unknown but it is currently under study.

Part of this work was supported by grants from PNCB of the CONACYT, and the Direccion General de Investigación Científica y Superación Académica from the Subsecretaría de Educación Superior e Investigación Científica, SEP, México. Travel expenses and support of G. Larriba were provided by the C.S.I.C. from Spain and the Conacyt and CINVESTAV from México. The authors are indebted to Drs E. López-Romero and S. Bartnicki-García for useful discussions and criticism and to Mrs B. Chávez for expert technical assistance in electron microscopy.

\section{REFERENCES}

ASHWELL, G. (1957). Colorimetric analysis of sugars. Methods in Enzymology 3, 73-105.

Balint, S., Farkas, V. \& Bauer, S. (1976). Biosynthesis of $\beta$-glucans catalyzed by a particulate enzyme preparation from yeast. FEBS Letters 64, 44-47.

Bartnicki-García, S., Bracker, C. E., Reyes, E. \& Ruíz-HERRERA, J. (1978). Isolation of chitosomes from taxonomically diverse fungi and synthesis of chitin microfibrils in vitro. Experimental Mycology 2, 173-192.

BLuHM, T. L. \& SARKo, A. (1977). The triple helical structure of lentinan, a linear $1,3-\beta$-D-glucan. Canadian Journal of Chemistry 55, 293-299.

FleET, G. H. \& MANNERS, D. J. (1976). Isolation and composition of an alkali-soluble glucan from the cell walls of Saccharomyces cerevisiae. Journal of General Microbiology 94, 180-192.

KREGER, D. R. \& KopeCKA, M. (1976). On the nature and formation of the fibrillar nets produced by protoplasts of Saccharomyces cerevisiae in liquid media: an electron microscopic, X-ray diffraction and chemical study. Journal of General Microbiology 92, 207-220.

Larriba, G., Morales, M. \& Rúz-Herrera, J. (1980). Biosynthesis of yeast glucan microfibrils in vitro. Abstracts, 80th Annual Meeting of the American Society for Microbiology, Miami, Florida, K-29.
López-Romero, E. \& Ruíz-Herrera, J. (1977). Biosynthesis of $\beta$-glucan by cell-free extracts from Saccharomyces cerevisiae. Biochimica et biophysica acta 500, 372-384.

López-Romero, E. \& Rúz-Herrera, J. (1978), Properties of $\beta$-glucan synthetase from Saccharomyces cerevisiae. Antonie van Leeuwenhoek 44, 329-339.

Mannfrs, D. J., Mason, A. \& Patterson, J. C. (1973). The structure of a 1,3- $\beta$-D-glucan from yeast cell walls. Biochemical Journal 135, 19-30.

SAN BLAS, G. (1979). Biosynthesis of glucans by subcellular fractions of Paracoccidioides brasiliensis. Experimental Mycology 3, 249-258.

ShEMATEK, E. M. \& CABIB, E. (1980). Biosynthesis of yeast cell wall. II. Regulation of $1,3-\beta$-glucan synthetase by ATP and GTP. Journal of Biological Chemistry 255, 895-902.

Shematek, E., BraAtz, J. A. \& Cabib, E. (1980). Biosynthesis of yeast cell wall. I. Preparation and properties of $1,3-\beta$-glucan synthetase. Journal of Biological Chemistry 255, 888-894.

Trevelyan, W. E., Procter, D. P. \& Harrison, J. S. (1950). Detection of sugars on paper chromatograms. Nature, London 166, 444-445.

WANG, M. C. \& BARTNICKI-GARCía, S. (1976). Synthesis of $1,3-\beta$-glucan microfibrils by a cell-free extract from Phytophthora cinnamomi. Archives of Biochemistry and Biophysics 175, 351-354. 